\title{
БІЛКОВО-ПРОТЕЇНАЗНИЙ КОМПЛЕКС ЗЕРНА СОРТІВ ПШЕНИЦІ СПЕЛЬТИ ЗАЛЕЖНО ВІД УДОБРЕННЯ
}

\author{
Г. М. Господаренко, доктор сільськогосподарських наук \\ В. В. Любич, доктор сільськогосподарських наук \\ В. В. Новіков, кандидат технічних наук \\ В. В. Желєзна, кандидат сільськогосподарських наук \\ Уманський національний університет садівництва
}

Встановлено, щзо вміст білка в зерні пшениці спельти сорту Зоря України, вирощеному на неудобрених ділянках становив 19,9\% $і$ зростав до 23,4-24,0\% за одноразового підживлення $N_{120}$ або на 18-21\% i до 24,5$25,1 \%$ за роздрібного застосування азотних добрив $\left(N_{60}+N_{60}\right)$ або на 23$26 \%$. У зерні сорту Свропа він зростав відповідно від 18,7\% до 21,7-22,3 i до 22,6-23,2\%. Зерно пшенищі спельти Зоря України має вищу біологічну цінність за вмістом есенційних амінокислот, оскільки їхній скор був бездефіциитним.

Ключові слова: пшениця спельта, удобрення, вміст білка, вміст амінокислот, амінокислотний скор.

Постановка проблеми. Застосування мінеральних добрив один із найважливіших заходів у технології вирощування пшениці спельти, що забезпечує підвищення врожайності та якості зерна [4-7]. Проте рослини пшениці спельти за внесення високих доз азотних добрив вилягають, що негативно впливає на формування iї продуктивності [1]. Тому цю культуру слід вирощувати після парових попередників без застосування азотних добрив. Лише за умови вирощування на грунтах важкого гранулометричного складу доцільно вносити 30-60 кг/га д. р. азотних добрив [9].

Аналіз останніх досліджень і публікацій. У дослідах $[8,9]$ підживлення різних сортів пшениці спельти азотними добривами підвищувало вміст білка та клейковини у зерні. При цьому в складі білка найбільше зростала частка гліадину порівняно з іншими фракціями. Це зазвичай сприяло формуванню еластичнішого тіста та зниженню об'єму хліба. Ефективність застосування азотних добрив залежить від генетичних особливостей сорту.

Дослідженнями румунських вчених [10] встановлено, що застосування азотних добрив роздрібно по 25 кг/га д. р. підвищувало масу 1000 зерен з 48,1 г до 48,8 г, а вміст білка - $312,7 \%$ до 13,1\%. Ефективність застосування добрив залежала від сорту пшениці спельти.

Мала кількість наукових публікацій свідчить, що в умовах Правобережного Лісостепу вплив удобрення на технологічні властивості зерна пшениці спельти вивчено недостатньо, що зумовлює необхідність проведення досліджень. 
Методика досліджень. Досліджували сорти пшениці спельти озимої Зоря України, отриманого методом індивідуально-родинного добору 3 місцевого сорту Буковинський 1 і Свропа - гібридизацією Triticum aestivum L. / Triticum spelta L. Пшеницю спельту вирощували за системами удобрення, представленими в табл. 1.

Табл. 1. Схема досліду з вивчення ефективності удобрення

\begin{tabular}{|l|c|c|c|c|}
\hline \multirow{2}{*}{ Варіант досліду } & \multicolumn{3}{|c|}{ Доза мінеральних добрив, кг/га д. $\mathrm{p}}$. \\
\cline { 2 - 3 } & \multicolumn{2}{|c|}{$\mathrm{N}$} & \multirow{2}{*}{$\mathrm{P}_{2} \mathrm{O}_{5}$} & \multirow{2}{*}{$\mathrm{K}_{2} \mathrm{O}$} \\
\cline { 2 - 5 } & 1 & 2 & - & - \\
\hline Без добрив (контроль) & - & - & 60 & - \\
\hline $\mathrm{P}_{60}+\mathrm{N}_{120}$ & 120 & - & - & 60 \\
\hline $\mathrm{K}_{60}+\mathrm{N}_{120}$ & 120 & - & 60 & 60 \\
\hline $\mathrm{P}_{60} \mathrm{~K}_{60}-$ фон & - & - & 60 & 60 \\
\hline фон $+\mathrm{N}_{120}$ & 120 & - & 60 & 60 \\
\hline фон $+\mathrm{N}_{60}+\mathrm{N}_{60}$ & 60 & 60 & 60 & 60 \\
\hline фон $+\mathrm{N}_{60} \mathrm{~S}_{70}+\mathrm{N}_{60}$ & 60 & 60 & 60 \\
\hline
\end{tabular}

Примітка. Підживлення: 1 - напровесні, 2 - у фазу початку виходу в трубку.

Добрива вносили у вигляді аміачної селітри, сульфату амонію, суперфосфату гранульованого та калію хлористого. Загальна площа дослідної ділянки становила $72 \mathrm{~m}^{2}$, облікової - $40 \mathrm{~m}^{2}$, повторність досліду триразова, розміщення ділянок послідовне. Попередник - викоовес на зелений корм. Закладання польових дослідів, проведення спостережень i досліджень проводили відповідно методичних рекомендацій [2].

У зерні пшениці спельти визначали вміст білка - за ДСТУ 4117:2007, вміст амінокислот (сума фракцій лейкозин + глобулін + глютенін + гліадин) методом іонообмінної рідинної хроматографії на аналізаторі амінокислот Т339.

Амінокислотний скор визначали за такою формулою [3]:

$$
A=\frac{\Phi}{O} \times 100,
$$

де А - амінокислотний скор, \%;

$\Phi-$ фактичний вміст амінокислоти, мг/г зерна;

$\mathrm{O}$ - оптимальний вміст амінокислоти, мг/г зерна.

Інтегральний скор визначали за такою формулою [3]:

$$
A=\frac{\Phi}{д} \times 100
$$

де А - амінокислотний скор, \%; Ф - фактичний вміст амінокислоти, г/100 г зерна; Д - добова потреба амінокислот для організму дорослої людини, г.

Результати досліджень. Зерно сортів пшениці спельти характеризувалось високим вмістом білка. За внесення азотних добрив вміст якого істотно зростав (табл. 2). Так, у зерні сорту Зоря України на неудобрених ділянках він становив $19,9 \%$ та зростав до $23,4-24,0 \%$ за одноразового підживлення або на $18-21 \%$ і до $24,5-25,1 \% 3$ роздрібним 
застосуванням азотних добрив або на 23-26\% порівняно 3 контролем. Застосування азотних добрив підвищувало стабільність вмісту білка в зерні 3 0,88 до 0,95 .

Вміст білка змінювався залежно від погодних умов року дослідження. Краще забезпечення опадами та вилягання рослин у 2015 р. знижувало вміст білка до 18,5 \% проти 20,0-21,1 \% у 2013-2015 pр.

Вміст білка в зерні пшениці спельти сорту Європа був істотно нижчий порівняно з сортом Зоря України і зростав з 18,7 \% на контролі до 21,7-22,3 за одноразового підживлення азотними добривами дозою 120 кг/га д. p. і до 22,6-23,2 \% за роздрібного їх застосування. Вміст білка за роки досліджень змінювався подібно сорту Зоря України, проте індекс стабільності зростав 3 0,84 до 0,85 за роздрібного застосування азотних добрив.

Табл. 2. Вміст білка в зерні пшениці спельти за різного удобрення, \%

\begin{tabular}{|c|c|c|c|c|c|}
\hline \multirow{2}{*}{$\begin{array}{l}\text { Варіант досліду } \\
\text { (фактор А) }\end{array}$} & \multicolumn{3}{|c|}{ Рік } & \multirow{2}{*}{$\begin{array}{c}\text { Середнє } \\
\text { за три } \\
\text { роки }\end{array}$} & \multirow{2}{*}{$\begin{array}{c}\text { Індекс } \\
\text { стабіль- } \\
\text { ності }\end{array}$} \\
\hline & 2013 & 2014 & 2015 & & \\
\hline \multicolumn{6}{|c|}{ Сорт Зоря України (фактор В) } \\
\hline Без добрив (контроль) & 20,0 & 21,1 & 18,5 & 19,9 & 0,88 \\
\hline $\mathrm{P}_{60}+\mathrm{N}_{120}$ & 24,1 & 23,7 & 22,4 & 23,4 & 0,93 \\
\hline $\mathrm{K}_{60}+\mathrm{N}_{120}$ & 24,0 & 23,8 & 22,5 & 23,4 & 0,94 \\
\hline $\mathrm{P}_{60} \mathrm{~K}_{60}-\phi о \mathrm{H}$ & 19,8 & 21,0 & 18,6 & 19,8 & 0,89 \\
\hline$\Phi \mathrm{OH}+\mathrm{N}_{120}$ & 24,5 & 24,3 & 23,1 & 24,0 & 0,94 \\
\hline$\Phi$ oH $+\mathrm{N}_{60}+\mathrm{N}_{60}$ & 25,2 & 24,7 & 23,7 & 24,5 & 0,94 \\
\hline$\Phi \mathrm{OH}+\mathrm{N}_{60} \mathrm{~S}_{35}+\mathrm{N}_{60}$ & 25,7 & 25,2 & 24,3 & 25,1 & 0,95 \\
\hline \multicolumn{6}{|c|}{ Сорт Свропа } \\
\hline Без добрив (контроль) & 19,5 & 20,0 & 16,7 & 18,7 & 0,84 \\
\hline $\mathrm{P}_{60}+\mathrm{N}_{120}$ & 23,5 & 22,8 & 19,0 & 21,8 & 0,81 \\
\hline $\mathrm{K}_{60}+\mathrm{N}_{120}$ & 23,5 & 22,9 & 18,8 & 21,7 & 0,80 \\
\hline $\mathrm{P}_{60} \mathrm{~K}_{60}-\phi о \mathrm{\phi}$ & 19,6 & 19,7 & 16,9 & 18,7 & 0,86 \\
\hline$\Phi \mathrm{OH}+\mathrm{N}_{120}$ & 23,6 & 23,5 & 19,9 & 22,3 & 0,84 \\
\hline$\Phi \mathrm{OH}+\mathrm{N}_{60}+\mathrm{N}_{60}$ & 23,4 & 24,0 & 20,5 & 22,6 & 0,85 \\
\hline$\Phi$ OH $+\mathrm{N}_{60} \mathrm{~S}_{35}+\mathrm{N}_{60}$ & 24,2 & 24,5 & 20,9 & 23,2 & 0,85 \\
\hline \multirow{2}{*}{ 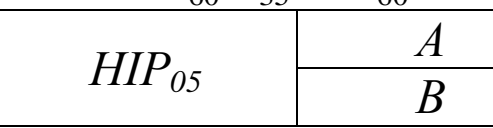 } & 0,6 & 0,5 & 0,4 & - & - \\
\hline & 0,5 & 0,5 & 0,4 & - & - \\
\hline
\end{tabular}

Покращення азотного живлення рослин пшениці спельти за рахунок застосування азотних добрив підвищувало вміст амінокислот у зерні. При цьому встановлено, що в складі ессенціальних амінокислот найвищим був вміст ізолейцину - 1,23 \% у варіанті без добрив і 1,37-1,38 \% за внесення фосфорних і азотних чи калійних і азотних добрив або більший на 11-12 \% i $1,40-1,42 \%$ за роздрібного застосування азотних добрив, або більше на 14 $15 \%$. Найменше у зерні було метіоніну, вміст якого збільшувався від 0,15\% у варіанті без добрив до $0,35 \%$ за внесення $\mathrm{N}_{60}+\mathrm{N}_{60}$ або в 2,3 раза порівняно 
3 контролем. Вміст решти ессенціальних амінокислот підвищувався на 18 $78 \%$. Проте частка ессенціальних амінокислот від їхньої суми становила лише 30-32 \% залежно від варіанту досліду.

Вміст замінних амінокислот змінювався від 12,27 до 15,27 \% залежно від удобрення і підвищувався на 9-44 \% 3 покращенням азотного живлення. Найвищий їхній вміст забезпечувало застосування $\mathrm{N}_{60} \mathrm{~S}_{35}+\mathrm{N}_{60}$ на тлі $\mathrm{P}_{60} \mathrm{~K}_{60}$. Крім цього вміст метіоніну зростав в 3,3 раза, а цистину - в 1,7 раза порівняно з неудобреними ділянками.

Вміст суми амінокислот у зерні пшениці спельти сорту Європа був меншим на 19-20 \% порівняно з сортом Зоря України. Зерно пшениці спельти Зоря України має найвищу біологічну цінність за вмістом ессенціальних амінокислот, оскільки їхній скор був бездефіцитним (табл. 3).

Табл. 3. Амінокислотний скор ессенціальних амінокислот у зерні пшениці спельти за різного удобрення (2013-2015 рр.), \%

\begin{tabular}{|c|c|c|c|c|c|c|c|c|}
\hline \multirow[b]{2}{*}{$\begin{array}{l}\text { Аміно- } \\
\text { кислота }\end{array}$} & \multirow{2}{*}{$\begin{array}{c}\text { Еталон } \\
\text { ФАО/В } \\
\text { ООЗ, } \\
\%\end{array}$} & \multicolumn{7}{|c|}{ Варіант досліду } \\
\hline & & $\begin{array}{c}\text { Без } \\
\text { добрив } \\
\text { (контроль) }\end{array}$ & $\begin{array}{r}\mathrm{P}_{60}+ \\
\mathrm{N}_{120}\end{array}$ & $\begin{array}{r}\mathrm{K}_{60}+ \\
\mathrm{N}_{120}\end{array}$ & $\begin{array}{c}\mathrm{P}_{60} \mathrm{~K}_{60}- \\
\text { фон }\end{array}$ & $\begin{array}{c}\text { Фон + } \\
\mathrm{N}_{120}\end{array}$ & $\begin{array}{c}\text { ФоH + } \\
\mathrm{N}_{60}+\mathrm{N}_{60}\end{array}$ & $\mid \begin{array}{c}\text { Фон }+ \\
\mathrm{N}_{60} \mathrm{~S}_{35}+ \\
\mathrm{N}_{60}\end{array}$ \\
\hline \multicolumn{9}{|c|}{ Сорт Зоря України } \\
\hline Лi3 & 0,61 & 108 & 141 & 141 & 108 & 146 & 151 & 152 \\
\hline Вал & 0,55 & 138 & 156 & 158 & 140 & 160 & 164 & 165 \\
\hline Мет+цис & 0,39 & 138 & 200 & 203 & 138 & 213 & 221 & 295 \\
\hline Tpe & 0,44 & 139 & 180 & 182 & 139 & 186 & 189 & 191 \\
\hline Лей & 0,77 & 160 & 178 & 179 & 160 & 181 & 182 & 184 \\
\hline Іле & 0,44 & 193 & 234 & 236 & 193 & 239 & 243 & 248 \\
\hline Три & 0,11 & 209 & 336 & 345 & 209 & 355 & 373 & 382 \\
\hline Фен+тир & 0,66 & 224 & 289 & 288 & 208 & 298 & 303 & 312 \\
\hline \multicolumn{9}{|c|}{ Сорт Європа } \\
\hline Лi3 & 0,61 & 66 & 84 & 84 & 66 & 85 & 85 & 89 \\
\hline Мет+цис & 0,39 & 95 & 141 & 138 & 95 & 144 & 156 & 213 \\
\hline Tpe & 0,44 & 95 & 136 & 136 & 95 & 139 & 145 & 166 \\
\hline Вал & 0,55 & 115 & 145 & 144 & 113 & 144 & 147 & 153 \\
\hline Лей & 0,77 & 125 & 152 & 151 & 123 & 152 & 153 & 156 \\
\hline Іле & 0,44 & 134 & 161 & 164 & 134 & 164 & 164 & 164 \\
\hline Фен+тир & 0,66 & 138 & 179 & 180 & 138 & 182 & 185 & 194 \\
\hline Три & 0,11 & 200 & 327 & 345 & 200 & 336 & 345 & 364 \\
\hline
\end{tabular}

Поліпшення азотного живлення рослин пшениці спельти підвищувало амінокислотний скор. Слід зазначити, що найбільше він зростав для 
триптофану та фенілаланіну - на 88-173 пункти порівняно 3 контролем (відповідно 209 і $224 \%$ ).

Біологічна цінність зерна пшениці спельти сорту Європа була нижчою порівняно з сортом Зоря України, оскільки амінокислотний скор лізину був у дефіциті - 66-89 \%. Амінокислотний скор решти ессенціальних амінокислот був бездефіцитним.

Інтегральний скор амінокислот також сильно змінювався залежно від застосування азотних добрив (табл. 4). Найбільше біологічну потребу задовольняло 100 г зерна пшениці спельти сорту Зоря України ізолейцином $\mathrm{i}$ триптофаном, дещо менше валіном, гістидином, глютаміновою кислотою та проліном - на 30-43 \%, а найменше метіоніном, аспарагіновою кислотою та аланіном - на 7-27 \% залежно від варіанту досліду.

Табл. 4. Інтегральний скор амінокислот 100 г зерна пшениці спельти сорту Зоря України за різного удобрення (2013-2015 рр.), \%

\begin{tabular}{|c|c|c|c|c|c|c|c|c|}
\hline \multirow[b]{2}{*}{$\begin{array}{l}\text { Аміно- } \\
\text { кислота }\end{array}$} & \multirow[b]{2}{*}{$\begin{array}{c}\text { Добова } \\
\text { потреба, } \\
\Gamma\end{array}$} & \multicolumn{7}{|c|}{ Варіант досліду } \\
\hline & & $\begin{array}{c}\text { Без } \\
\text { добрив } \\
\text { (контроль) }\end{array}$ & $\begin{array}{r}\mathrm{P}_{60}+ \\
\mathrm{N}_{120}\end{array}$ & $\begin{array}{r}\mathrm{K}_{60}+ \\
\mathrm{N}_{120}\end{array}$ & $\begin{array}{c}\mathrm{P}_{60} \mathrm{~K}_{60}- \\
\text { фон }\end{array}$ & $\begin{array}{c}\text { Фон }+ \\
\mathrm{N}_{120}\end{array}$ & $\begin{array}{c}\Phi \mathrm{OH}+ \\
\mathrm{N}_{60}+ \\
\mathrm{N}_{60}\end{array}$ & $\begin{array}{c}\Phi \mathrm{oH}+ \\
\mathrm{N}_{60} \mathrm{~S}_{35}+ \\
\mathrm{N}_{60}\end{array}$ \\
\hline Мет & 1,8 & 8 & 17 & 17 & 9 & 18 & 19 & 27 \\
\hline Лi3 & 4,1 & 16 & 21 & 21 & 16 & 22 & 22 & 23 \\
\hline Фен & 4,4 & 19 & 25 & 25 & 18 & 26 & 26 & 27 \\
\hline Tpe & 2,4 & 25 & 33 & 33 & 25 & 34 & 35 & 35 \\
\hline Лей & 4,6 & 27 & 30 & 30 & 30 & 26 & 30 & 31 \\
\hline Три & 0,8 & 29 & 46 & 48 & 29 & 49 & 51 & 53 \\
\hline Вал & 2,5 & 30 & 34 & 35 & 31 & 35 & 36 & 36 \\
\hline Іле & 2,0 & 43 & 52 & 52 & 43 & 53 & 54 & 55 \\
\hline Aсп & 12,2 & 7 & 10 & 10 & 7 & 10 & 10 & 11 \\
\hline Ала & 6,6 & 9 & 12 & 12 & 9 & 13 & 13 & 13 \\
\hline Арг & 6,1 & 13 & 15 & 15 & 13 & 15 & 16 & 16 \\
\hline Cep & 8,3 & 13 & 15 & 15 & 13 & 16 & 16 & 16 \\
\hline Тир & 4,4 & 15 & 18 & 18 & 13 & 19 & 19 & 20 \\
\hline Цис & 1,8 & 22 & 26 & 27 & 21 & 28 & 28 & 37 \\
\hline Глі & 3,5 & 23 & 26 & 25 & 23 & 27 & 28 & 28 \\
\hline Гic & 2,1 & 34 & 41 & 40 & 33 & 42 & 43 & 44 \\
\hline Глю & 13,6 & 34 & 39 & 39 & 33 & 39 & 40 & 40 \\
\hline Про & 4,5 & 40 & 41 & 41 & 39 & 43 & 43 & 43 \\
\hline
\end{tabular}

Забезпечення добової потреби амінокислотами 100 г зерна пшениці спельти сорту Свропа було меншим порівняно з сортом Зоря України (табл. 5). 
Табл. 5. Інтегральний скор амінокислот 100 г зерна пшениці спельти сорту Європа за різного удобрення (2013-2015 рр.), \%

\begin{tabular}{|c|c|c|c|c|c|c|c|c|}
\hline \multirow[b]{2}{*}{$\begin{array}{l}\text { Аміно- } \\
\text { кислота }\end{array}$} & \multirow[b]{2}{*}{$\begin{array}{c}\text { Добова } \\
\text { потреба, } \\
\Gamma\end{array}$} & \multicolumn{7}{|c|}{ Варіант досліду } \\
\hline & & $\begin{array}{l}\text { Контроль } \\
\text { (без добрив) }\end{array}$ & $\begin{array}{r}\mathrm{P}_{60}+ \\
\mathrm{N}_{120}\end{array}$ & $\begin{array}{r}\mathrm{K}_{60}+ \\
\mathrm{N}_{120}\end{array}$ & $\begin{array}{c}\mathrm{P}_{60} \mathrm{~K}_{60}- \\
\text { фоH }\end{array}$ & $\begin{array}{c}\text { Фон + } \\
\mathrm{N}_{120}\end{array}$ & $\begin{array}{c}\Phi \mathrm{OH}+ \\
\mathrm{N}_{60}+ \\
\mathrm{N}_{60} \\
\end{array}$ & $\begin{array}{c}\Phi \mathrm{\Phi H}+ \\
\mathbf{N}_{60} \mathrm{~S}_{35}+ \\
\mathrm{N}_{60} \\
\end{array}$ \\
\hline Мет & 1,8 & 6 & 10 & 9 & 6 & 9 & 10 & 14 \\
\hline Лi3 & 4,1 & 10 & 12 & 12 & 10 & 13 & 13 & 13 \\
\hline Фен & 4,4 & 13 & 17 & 18 & 13 & 18 & 18 & 19 \\
\hline Tpe & 2,4 & 18 & 25 & 25 & 18 & 25 & 27 & 30 \\
\hline Лей & 4,6 & 21 & 25 & 25 & 21 & 25 & 26 & 26 \\
\hline Вал & 2,5 & 25 & 32 & 32 & 25 & 32 & 32 & 34 \\
\hline Три & 0,8 & 28 & 45 & 48 & 28 & 46 & 48 & 50 \\
\hline Іле & 2,0 & 30 & 36 & 36 & 30 & 36 & 36 & 36 \\
\hline Асп & 12,2 & 6 & 7 & 7 & 6 & 7 & 7 & 7 \\
\hline Ала & 6,6 & 7 & 9 & 9 & 7 & 9 & 10 & 10 \\
\hline Тир & 4,4 & 8 & 10 & 10 & 8 & 10 & 10 & 10 \\
\hline Cep & 8,3 & 9 & 11 & 11 & 9 & 11 & 11 & 12 \\
\hline Арг & 6,1 & 11 & 12 & 12 & 11 & 12 & 12 & 12 \\
\hline Цис & 1,8 & 15 & 21 & 21 & 14 & 22 & 24 & 32 \\
\hline Глі & 3,5 & 17 & 19 & 19 & 17 & 19 & 20 & 20 \\
\hline Гic & 2,1 & 22 & 27 & 28 & 23 & 27 & 28 & 29 \\
\hline Глю & 13,6 & 33 & 36 & 36 & 33 & 36 & 36 & 37 \\
\hline Про & 4,5 & 34 & 39 & 39 & 34 & 39 & 40 & 41 \\
\hline
\end{tabular}

Висновки. Вміст білка в зерні пшениці спельти сорту Зоря України, вирощеному на неудобрених ділянках становив 19,9\% і зростає до 23,4$24,0 \%$ за одноразового підживлення $\mathrm{N}_{120}$ або на $18-21 \%$ і до 24,5-25,1\% за роздрібного застосування азотних добрив $\left(\mathrm{N}_{60}+\mathrm{N}_{60}\right)$ або на $23-26 \%$. У зерні сорту Свропа він зростав відповідно від 18,7 \% до 21,7-22,3 і до 22,6$23,2 \%$.

Зерно пшениці спельти Зоря України має вищу біологічну цінність за вмістом есенційних амінокислот, оскільки їхній скор був бездефіцитним. Найбільше біологічну потребу 100 г зерна пшениці спельти сорту Зоря України задовольняє ізолейцином і триптофаном - на 29-55 \%; валіном, гістидином, глутаміновою кислотою і проліном - на 30-43; найменше метіоніном, аспарагіновою кислотою і аланіном - на 7-27\% залежно від варіанту удобрення.

Забезпечення добової потреби амінокислотами 100 г зерна пшениці спельти сорту Європа менше порівняно з сортом Зоря України. 


\section{Література}

1. Господаренко Г. М., Полторецький С. П., Любич В. В., Новіков В. В., Желєзна В. В., Воробйова Н. В., Улянич І. Ф. Формування якості макаронів і кондитерських виробів із зерна пшениці спельти. Вісник аграрної науки Причорномор'я. Миколаїв. 2018. Вип. 1. С. 199-210.

2. Сщенко В. О., Копитко П. Г., К Костогриз П. В., Опришко В. П. Основи наукових досліджень в агрономії. Вінниця: ПП ТД «Едельвейс і К». 2014. $332 \mathrm{c}$.

3. Казаков Е. Д., Карпиленко Г. П. Биохимия зерна и хлебопродуктов. Санкт-Петербург: ГИОРД. 2005. 512 с.

4. Любич В. В. Ознаки якості хліба різного борошна сортів і ліній пшениць. Збірник Уманського НУС. Умань. 2018. Вип. 92. С. 64-76.

5. Патика В. П., Карпенко В. П., Любич В. В. Азотовмісні сполуки у зерні різних сортів і ліній пшениці спельти. Вісник аграрної науки. 2018. № 8. C. $17-23$.

6. Abdelkhalik S. M., $\quad$ Salem A. K. M., $\quad$ Bdelaziz A. R., $\quad$ Ammar M. H. Morphological and sequence-related amplifed polymorphism-based molecular diversity of local and exotic wheat genotypes. Genetics and Molecular Research. 2016. Vol. 15 (2). P. 1-9.

7. Dolijanovic Z., Oljaca S., Kovacevic D., Đorđević S., Brdarthe J. Effects of different fertilizers on spelt grain yield (Triticum aestivum L. ssp spelta) // IV International Symposium «Agrosym 2013». 2013. P. 506-510.

8. Graybosch R. A., Peterson C. J., Shelton D. R., Baenziger P. S. Genotypic and environmental modification of wheat flour protein composition $\mathrm{n}$ relation to end-use quality. Crop Sc. 1996. V. 36. № 2. P. 296-300.

9. Grela E. R. Nutrient composition and content of antinutritional factors in spelt (Triticum spelta L.) cultivars. J. Sci. Food Agric. 71. 1996. № 71. P. 399-404.

10. Kohajdová Z. 1., Karovičová J. Effect of incorporation of spelt flour on the dough properties and wheat bread quality. Żywność. Nauka. Technologia. Jakość. 2007. № 4 (53). P. 36-45.

\section{References}

1. Hospodarenko, G. M., Poltoretskyi, S. P., Liubych, V. V. et al. (2018). Quality formation of spelt wheat macaroni and confectionery products. Ukrainian Black Sea region agrarian science, 2018, no. 1, pp. 199-210 (in Ukrainian).

2. Eshchenko, V.O., Kopytko, P.H., Opryshko, V.P. et al. (2005). Basic scientific research in agronomy. Kyiv: Diya, 2005, 286 p. (in Ukrainian).

3. Kazakov, E.D., Karpilenko, G.P. (2005). Biochemistry of grain and grain products. St. Petersburg: GIORD, 2005. 512 p. (in Russian).

4. Liubych, V.V. (2018). Quality features of bread made of different flour of wheat varieties and strains. Collected Works of Uman National University of Horticulture, 2018, no. 92, pp. 64-76 (in Ukrainian).

5. Patyka, V.F., Karpenko, V.P., Liubych, V.V. (2018). Nitrogen-containing compounds in the grain of different spelt wheat varieties and strains. News of 
agrarian sciences, 2018, no. 8, pp. 17-23 (in Ukrainian).

6. Abdelkhalik, S. M., Salem, A. K. M., Bdelaziz, A. R., Ammar, M. H. (2016). Morphological and sequence-related amplifed polymorphism-based molecular diversity of local and exotic wheat genotypes. Genetics and Molecular Research, 20166 no. 15 (2). pp. 1-9 (in English).

7. Dolijanovicб Z., Oljaca, S., Kovacevic, D., Đorđević, S., Brdarthe, J. (2013). Effects of different fertilizers on spelt grain yield (Triticum aestivum L. ssp spelta). IV International Symposium «Agrosym 2013», 2013, pp. 506-510 (in English).

8. Graybosch, R. A., $\quad$ Peterson, C. J., Shelton, D. R., Baenziger, P. S. Genotypic and environmental modification of wheat flour protein composition $\mathrm{n}$ relation to end-use quality. Crop Sc, 1996, no. 36, pp. 296-300 (in English).

9. Grela, E. R. (1996). Nutrient composition and content of antinutritional factors in spelt (Titicum spelta L.) cultivars. J. Sci. Food Agric, 1996, no. 71, pp. 399-404 (in English).

10. Kohajdová, Z. 1., Karovičová, J. (2007). Effect of incorporation of spelt flour on the dough properties and wheat bread quality. Żywność. Nauka. Technologia. Jakość., 2007, no.53, pp. 36-45 (in English).

\section{Аннотация}

Господаренко Г. М., Любич В. В., Новиков В.В., Железная В. В.

Белково-протеиназный комплекс зерна сортов пиеницы спельты в зависимости от удобрения

В результате проведенных исследований установлено, что зерно сортов пшеницы спельты характеризовалось высоким содержанием белка, которое существенно возрастало за внесения азотных удобрений. Так, содержание белка в зерне сорта Заря Украины на неудобрених участках составляло 19,9\% и увеличивалось до 23,4-24,0\% при однократной подпитки или на 18-21\% и до 24,5-25,1\% с дробным применением азотных удобрений или на 23-26\% по сравнению с контролем. Применение азотных удобрений повышало стабильность содержания белка в зерне с 0,88 до 0,95.

Содержание белка в зерне пшенииы спельты сорта Европа было существенно ниже по сравнению с сортом Заря Украины и увеличивалось с 18,7\% в контроле до 21,7-22,3 при однократной подкормке азотными удобрениями дозой 120 кг/га д. в. и до 22,6-23,2\% при дрробном их применении.

Применение азотных удобрений повымало содержание аминокислот в зерне пшеницы спельты. Установлено, что в составе эссенииальных аминокислот высоким было содержание изолейцина - 1,23\% на варианте без удобрений и 1,37-1,38\% за внесения фосфорных и азотных или калийных и азотных удобрений или больше на 11$12 \%$ и 1,40-1,42\% за дробного применения азотных удобрений, или больше на 14-15\%.

Содержание заменимых аминокислот менялось от 12,27 до 15,27 \% в зависимости от удобрения и повышалось на 9-44 \% с улучшением азотного питания растений. Самое высокое их содержание обеспечивало применение $N_{60} S_{35}+N_{60}$ на фоне $P_{60} K_{60}$. Кроме этого содержание метионина было выме в 3,3 раза, а ичистина - в 1,7 раза по сравнению с неудобреньми участками.

Содержание суммы аминокислот в зерне пшенищь спельты сорта Европа было меньше на 19-20\% по сравнению с сортом Заря Украиньл.

Зерно пшеницы спельты Заря Украины имеет высокую биологическую иенность по содержанию эссенциальных аминокислот, поскольку их скор был бездефицитным. Улучшение азотного питания растений пшеницы спельты повышало аминокислотный 
скор.

Биологическая иенность зерна пшеницы спельты сорта Европа была ниже сорта Зоря Украины, поскольку аминокислотный скор лизина был в дефиците - 66-89\%. Аминокислотный скор остальных эссенцииальных аминокислот был бездефицитным.

Интегральный скор аминокислот также сильно изменялся в зависимости от особенностей азотного питания растений пшенииь спельть. Больше всего биологическую потребность удовлетворяло 100 г зерна сорта Заря Украины изолейцином и триптофаном - на 29-55\%, несколько меньше (на 30-43\%) валином, гистидином, глутаминовой кислотой и пролином, а меньше всего метионином, аспарагиновой кислотой и аланином - на 7-27 \% в зависимости от варианта опыта.

Обеспечения суточной потребности аминокислотами 100 г зерна пшениць спельты сорта Европа было меньше по сравнению с сортом Заря Украины.

Ключевые слова: пиеница спельты, удобрения, содержание белка, содержание аминокислот, аминокислотньй скор.

\section{Annotation}

\section{Hospodarenko G. M. , Liubych V. V., Novikov V.V., Zheliezna V. V.}

Wheat and proteinatic complex of spelt wheat grain varieties depending on fertilizers

As a result of the conducted research, it has been found out that spelt wheat grain varieties was characterized by a high content of protein, the content of which significantly increased with the usage of nitrogen fertilizers. Thus, the protein content of grain of Zoria Ukrayiny variety in non-fertilized areas was $19.9 \%$ and increased to 23.4-24.0\% for one-time usage, or 18-21\% and to 24.5-25.1\% with gradual use of nitrogen fertilizers or by 23-26\% compared with controlled usage. The application of nitrogen fertilizers increased the stability of protein content in grain from 0.88 to 0.95 .

Protein content in spelt wheat grain of Yevropa variety was significantly lower than that of Zoria Ukrayiny, and increased from 18.7\% during the control to 21.7-22.3 with a single usage of nitrogen fertilizers at a dose of $120 \mathrm{~kg} / \mathrm{ha}$ and up to 22,6-23.2\% with gradual usage.

Usage of nitrogen fertilizers increased the content of aminoacids in spelt wheat grain. It has been found out that the content of isoleucine was the highest in the composition of the essential amino acids $-1.23 \%$ in case of no fertilizers usage, and 1.37-1.38\% with the input of phosphoric nitrogen and potassium nitrogen fertilizers, or higher by $11-12 \%$ and $1.40-1,42 \%$ with gradual usage of nitrogen fertilizers, or more by $14-15 \%$.

The content of the substituted amino acids varied from 12.27 to $15.27 \%$ depending on the fertilizer and increased by 9-44\% with the improvement of nitrogen supply. Their highest content provided $N_{60} S_{35}+N_{60}$ with $P_{60} K_{60}$ usage. In addition, the content of methionine increased by 3.3 times, and cystine - 1.7 times compared with unchecked areas.

The amount of amino acids in spelt wheat grain of Yevropa variety was smaller by $19-20 \%$ compared with Zoria Ukrayiny variety.

Spelt wheat grain of Zoria Ukrayiny variety has the highest biological value in terms of the content of essential amino acids, because its score was self-supporting. Improvement of nitrogen nutrition of spelt wheat grain increased the amino acid score.

Biological value of spelt wheat grain of Yevropa variety was lower, because amino acid score of lysine was deficient - 66-89\%. The amino acid score of the essential amino acids was self-supporting.

The integral score of amino acid also varies greatly depending on the usage of nitrogen fertilizers. The greatest biological need was met by $100 \mathrm{~g}$ of spelt wheat grain of Zoria Ukrayiny variety with isoleucine and tryptophan, somewhat less with valine, histidine, glutamic acid and proline - by 30-43\%, and the least with methionine, aspartic acid and alanine, by 7-27\% depending on the experiment option.

Provision of daily needs by amino acids $100 \mathrm{~g}$ of spelt wheat grain of Yevropa variety was smaller compared to Zoria Ukrayiny variety.

Key words: spelt wheat, fertilizers, protein content, amino acid content, amino acid score. 